\title{
Accomplishments, engagements and new challenges for the Monaldi Archives for Chest Disease
}

\author{
Antonio Spanevello, ${ }^{1}$ Bruno Balbi ${ }^{2}$ \\ ${ }^{1}$ Dipartimento di Medicina e Riabilitazione Cardio Respiratoria, ICS Maugeri, IRCCS Tradate (VA); \\ ${ }^{2}$ ICS Maugeri IRCCS, Veruno (NO), Italy
}

Another year has passed, and we would like to thank and recognize all of the many members who have contributed to the editorial process and content of the Monaldi Archives for Chest Disease during 2018.

Our submissions are increasing, citations for our papers are rising, and recognition of the journal is broadening.

Not settled for focusing on past goings-on only, we now direct our efforts toward building an even greater impact.

Important contributors to a scientific journal include all submitting authors; the Editorial Board members (Cardiac and Respiratory); the Monaldi Archives for Chest Disease office team and the Editorial Review Board members.

We also extend our sincere appreciation to all authors who submitted manuscripts for consideration for publication in the Monaldi Archives for Chest Disease: their work represents the most valued content of this Journal and contributes to the vitality and advancement of our profession and fields of interest.

Of particular significance to ensuring the rigor, importance, and novelty of scientific contributions are our volunteer peer reviewers. Peer review remains a crucial phase of the scientific publication in upholding the integrity and quality of the journal, helping to ensure that the manuscripts published in Monaldi are key and valid studies.

Although reviewing is a volunteer task, it is not a thankless one. Reviewers have the gratitude of every author whose work has been improved by their comments and suggestions. The Editorial Board of the Monaldi Archives for Chest Disease acknowledges and appreciates that reviewers make our mission possible.

Last year, more than 100 reviewers were involved in the peerreview process. We are grateful to every single one. We appreciate the time and effort they devote to evaluate the manuscripts and provide important feedback to the authors and to the editors.

The efforts of this group are invisible to readers, but are unquestionably crucial to the scientific publication process. Many thanks, again, to you all, and particularly to all of those listed at the end of this Editors' Note - by providing who have contributed in this past year to excellent, timely, and constructive reviews.

Correspondence: Antonio Spanevello, Dipartimento di Medicina e Riabilitazione Cardio Respiratoria, ICS Maugeri, IRCCS Tradate, Via Roncaccio 16, 21049 Tradate (VA), Italy.

E-mail: antonio.spanevello@icsmaugeri.it

Received for publication: 25 March 2019.

Accepted for publication: 25 March 2019.

(C) Copyright A. Spanevello and B. Balbi, 2019

Licensee PAGEPress, Italy

Monaldi Archives for Chest Disease 2019; 89:1070

doi: 10.4081/monaldi.2019.1070

This article is distributed under the terms of the Creative Commons Attribution Noncommercial License (by-nc 4.0) which permits any noncommercial use, distribution, and reproduction in any medium, provided the original author(s) and source are credited.
We also would like to warmly welcome the Italian Association of Respiratory Physiotherapists (ARIR), whose members are joining the existing board of the Monaldi Archives for Chest Disease starting from this year. With their contribution, a new contest for the journal becomes true: the Physiotherapy Area will host papers in the field of cardio-pulmonary rehabilitation, with a particular attention to the advancement of the scientific level of the respiratory physiotherapy professionals. We wish a growing contribution from all health allied professional to this new section of our journal.

We sincerely look forward to working with all of you in the future.

Our warm thank to the following Contributors:

A. Abreu, M. Abrignani, W. Ageno, S. Agrawal, A. Aiello, T. Alfaro, S. Aliberti, G. Aloisi, M. Ambrosetti, N. Ambrosino, E. Angelino, F. Antonini Canterin, E. Bacci, F. Barillà, S. Baldasseroni, B. Beghé, M. Beltrami, G. Bertorelli, O. Bettinardi, A. Bianco, A. Biffi, F. Bini, E. Biskup, R. Boffi, A. Boccanelli, B. Bodini, F. Bonella, B. Bordoni, E. Bossone, G. Botto, A. Braghiroli, F. Braido, C. Bruschi, C. Bucca, C. Calabrese, A. Caminati, M. Caminati, P. Caponnetto, F. Cappello, G. Caramori, M. Carone, R. Carlon, A. Carminati, M. Carone, G.E. Carpagnano, C. Casadio, M. Cazzola, P. Ceriana, E. Clini, F. Colivicchi, M. Confalonieri, S. Conte, M. Contoli, L. Corbetta, U. Corrà, A. Corsico, C. Crimi, N. Crimi, J. Daily, R. Dal Negro, S. De Feo, F. De Michele, M. Dębski, F. Dentali, G. Desideri, A. Di Lenarda, G. Di Maria, F. Di Marco, G. Di Pasquale, L. Dominioni, C.F. Donner, L.M. Fabbri, N. Facciolongo, G. Faden, P. Faggiano, F. Fattirolli, P. Faverio, G. Favretto, O. Febo, F. Ferrara, S. Fumagalli, A. Frisinghelli, M.P. Foschino Barbaro, G. Furgi, M. Gabriele, A. Galati, S. Gasparini, F. Giallauria, S. Gianpaoli, A. Genovesi Ebert, P. Giorgini, J. Gomberg, A. Gonfiotti, C. Grassi, R. Griffo, D. Hansen, S. Harari, L. Heaney, M.C. Iliou, A. Imperatori, P. Jacob, J. Kšela, V.P. Kuriachan, F. Lavorini, M.T. La Rovere, D. Lacedonia, E. Latorre, C. Letizia, A. Luna Maldonado, M. Lusuardi, M. Malerba, C. Mancusi, M. Maniscalco, P. Maras, G. Marenzi, A.M. Marra, M.G. Matera, A. Mazza, G. Mazzarella, F. Meloni, M. Metra, A. Mezzani, C. Micheletto, M. Miglioretti, G.B. Migliori, G.F. Mureddu, P. Muriana, F. Nardi, S. Nava, Z. Olivari, F. Orso, P. Paggiaro, A. Papi, A. Passantino, B. Passaretti, V. Patruno, G. Pelaia, P. Perrone Filardi, A. Pesci, P. Pignatti, M. Piepoli, L. Pini, M. Pistono, G. Polese, V. Poletti, S. Porcu, G.S. Pressman, S.G. Priori, C. Ravaglia, G. Rengo, F.L.M. Ricciardolo, C. Riccio, S. Riccobono, C. Robalo Cordeiro, D. Rocco, P. Rogliani, M. Romagnoli, N. Rotolo, C.R. Sacco, M. Salio, A. Salzano, A. Sanduzzi Zamparelli, P. Santus, S. Sarzi Braga, S. Scalvini, M. Schwab, E. Sciatti, N. Scichilone, D. Scrutinio, D. Simoni, P. Solidoro, M. Sommaruga, G. Sotgiu, P. Spagnolo, M. Spatafora, A. Squizzato, C. Tantucci, D. Tarantini, F. Tarro Genta, P.L. Temporelli, M. Tonelli, R. Torchio, P. Trambaiolo, E. Traversi, R. Trisolini, M. Uguccioni, S. Urbinati, C. Vancheri, A. Vatrella, C. Vigorito, D. Visca, P. Vitulo, M. Vitacca, M. Volterrani, M. Werren, D.H. Wiener, M. Zhao. 